\title{
NEOADJUVANT THERAPY AND SURGERY FOR RECTAL CANCER. Comparative study between partial and complete pathological response
}

\author{
Vitor Augusto de ANDRADE, Claudio Saddy Rodrigues COY, Raquel Franco LEAL, \\ João José FAGUNDES, Carlos Augusto Real MARTINEZ and \\ Maria de Lourdes Setsuko AYRIZONO
}

Received 13/1/2016

Accepted 28/3/2016

\begin{abstract}
Background - The approach of locally advanced extra-peritoneal rectal adenocarcinoma implies a treatment with neoadjuvant chemoradiotherapy associated with total mesorectal excision surgery. However, the tumors respond variably to this neoadjuvant therapy, and the mechanisms for response are not completely understood. Objective - Evaluate the variables related to the complete tumor response and the outcomes of patients who underwent surgery, comparing those with partial tumor regression and those with total remission of rectal lesion, at the pathological examination. Methods - Retrospective analysis of medical records of 212 patients operated between 2000 and 2010, in which 182 (85.9\%) obtained partial remission at neoadjuvant therapy (Group 1) and $30(14.1 \%)$, total remission (Group 2). Results - No difference was found between the groups in relation to gender, ethnicity, age, tumor distance from the anal verge, occurrence of metastases and synchronous lesions on preoperative staging, dose of radiotherapy and performed surgery. In Group 2, was verified high rate of complete remission when the time to surgery after neoadjuvant therapy was equal or less than 8 weeks $(P=0.027)$, and a tendency of lower levels of pretreatment carcinoembryonic antigen $(P=0.067)$. In pathological analysis, the Group 1 presented in relation to Group 2, more affected lymph nodes (average 1.9 and 0.5 respectively; $P=0.003$ ), more angiolymphatic $(19.2 \%$ and $3.3 \% ; P=0.032)$ and perineural involvement $(15.4 \%$ and $0 \% ; P=0.017)$ and greater number of lymph nodes examined (16.3 and 13.6; $P=0.023)$. In the late follow-up, Group 1 also had lower overall survival than Group 2 (94.1 months and 136.4 months respectively; $P=0.02)$ and disease-free survival ( 85.5 months and 134.6 months; $P=0.004)$. There was no statistical difference between Group 2 and Group 1 in local recurrence (15\% and 3.4\%, respectively) and distant metastasis (28\% and 13.8\%, respectively). Conclusion - In this study, the only factor associated with complete remission of rectal adenocarcinoma was the time between neoadjuvant therapy and surgery. This group of patients had less affected lymph nodes, less angiolymphatic and perineural involvement, a longer overall and disease-free survival, but no significant statistical difference was observed in local recurrence and distant metastasis. Although the complete pathologic remission was associated with better prognosis, this not implied in the cure of the disease for all patients.

HEADINGS - Neoadjuvant therapy. Colorectal surgery. Rectal neoplasms.
\end{abstract}

\section{INTRODUCTION}

The treatment of locally advanced extra-peritoneal rectal adenocarcinoma used for the last two decades, has been the association of preoperative chemoradiotherapy followed by resection surgery with total mesorectal excision ${ }^{(6)}$. The neoadjuvant therapy leads to a decrease of the lesion, facilitating the surgical resection and increasing the rates of sphincter preservation and maintenance of urinary and sexual functions $^{(11)}$. This multimodal approach is more effective in the control of local recurrence, but some studies also suggest an increase of survival rates.

The response of neoadjuvant therapy leads to reduction of tumor staging until the complete regression, defined as absence of cancer cells at the surgical specimen. Rates of $10 \%$ to $30 \%$ of complete tumor remission after neoadjuvant treatment are reported. For the metastatic lymph nodes, the neoadjuvant therapy also has effect at the regression, however, there might be maintenance of tumor cells even in patients with total regression of the tumor in the rectal wall, resulting in a reserved prognosis ${ }^{(3,11)}$.

Despite the large number of studies which evaluate the prognosis by clinical, pathological and molecular parameters, the histopathological classification of the surgical specimen is the most important information for the patients' prognosis ${ }^{(4,5,14,19)}$. So, the aim of this study was to evaluate the factors involved in tumor remission, comparing clinical and pathological 
data and the follow-up of patients who showed partial regression and complete remission of rectum lesion, at the surgical specimen.

\section{METHODS}

Patients with extra-peritoneal rectal adenocarcinoma, submitted to neoadjuvant radiotherapy and chemotherapy (5-fluorouracil and leucovorin) followed by total mesorectal excision surgery, were evaluated. The medical records of 212 patients operated from 2000 to 2010, by Colorectal Surgery Unit of the School of Medical Sciences, University of Campinas (UNICAMP) were analyzed. The study was approved by ethics committee of FCM-UNICAMP (No 727/2010).

Complete remission was defined as absence of tumor cells in the rectum, at the pathological study. The analysis of surgical specimen showed that there was presence of residual disease in 182 patients - 85.8\% (Group 1) and total tumor remission in the rectum in 30 patients $-14.2 \%$ (Group 2). A protocol was applied containing the following information: general characteristics (gender, ethnicity, age); preoperative data (level of carcinoembryonic antigen - CEA, distance between the tumor and the anal verge, presence of synchronous lesions in colonoscopy, staging exams, time between neoadjuvant therapy and surgery); surgical data (intraoperative findings and performed surgery); pathological analysis of the surgical specimen (histological grading of tumor, angiolymphatic and perineural involvement, number of examined and affected lymph nodes) and postoperative data (local recurrence, metastasis, deaths, disease-free survival and overall survival).

The comparison between the two groups was performed through the Mann-Whitney test for the numerical variables and through the Chi-square or Fisher exact test, for the categorical variables. The association between variables was done through binary logistic regression. At the multiple analysis, the selection criteria of variables, was the stepwise. The Cox proportional risks model was used to compare the overall survival and disease-free survival between groups. For all statistical tests, a $P$ value less that 0.05 was considered statistically significant.

\section{RESULTS}

The general characteristics and preoperative data are found in Table 1. In Group 1, 108 (59.3\%) patients had lesions located below $5 \mathrm{~cm}$ from anal verge, $67(36.8 \%)$ between 5 and $8 \mathrm{~cm}$ and $7(3.8 \%)$ above $8 \mathrm{~cm}$. In Group 2, $16(53.3 \%)$ patients showed rectal lesion below $5 \mathrm{~cm}$ from anal verge, 14 $(46.7 \%)$ between 5 and $8 \mathrm{~cm}$ and none above $8 \mathrm{~cm}(P=0.374)$.

Results of preoperative colonoscopy were not obtained in $7(3.3 \%)$ patients, all of them from Group 1. In this group, $10(5.7 \%)$ patients had stenosing lesion, not being possible to evaluate the proximal colon and in $43(26.1 \%)$ the presence of synchronous lesions was observed. In the other group, 2 $(6.7 \%)$ patients had stenosing lesion and $6(21.4 \%)$ synchronous lesions $(P=0.60)$.
TABLE 1. General characteristics and preoperative data

\begin{tabular}{lcccc}
\hline & Group 1 & Group 2 & Total & $P$ \\
\hline Gender & & & & \\
& & & & \\
(Male / Female) & $106 / 76$ & $18 / 12$ & $124 / 88$ & 0.856
\end{tabular}

Ethnicity

$\begin{array}{lcccc}\text { (White } / & 152 / 30 & 27 / 3 & 179 / 33 & 0.586 \\ \text { No white } & (83.5 / 16.5 \%) & (90.0 / 10.0 \%) & (84.4 / 15.6 \%) & \end{array}$

Mean age

$\begin{array}{cccc}\text { (years) } & 60.3 & 57.6 & 59.9 \\ (29-88) & (33-79) & (29-88) & 0.338\end{array}$

Metastases

$\begin{array}{llll}7(3.8 \%) & 0(0 \%) & 7(3.3 \%) & 0.597\end{array}$

$\begin{array}{lllll}\text { Liver } & 23(12.6 \%) & 1(3.3 \%) & 24(11.3 \%) & 0.212\end{array}$

CEA*

$\begin{array}{lllll}\leq 5 \mathrm{ng} / \mathrm{mL} & 86(48.6 \%) & 20(66.7 \%) & 106(51.2 \%) & \\ >5 \mathrm{ng} / \mathrm{mL} & 91(51.4 \%) & 10(33.3 \%) & 101(48.8 \%) & 0.067\end{array}$

Interval between neoadjuvant therapy and surgery

$\begin{array}{lllll}\leq 8 \text { weeks } & 84(51.2 \%) & 20(71.1 \%) & 104(54.4 \%) & \\ & & & \end{array}$

$>8$ weeks $\quad 80(48.8 \%) \quad 7(25.9 \%) \quad 87(45.5 \%)$

Radiotherapy dose

$\leq 4000 \mathrm{cGy} \quad 5(3.11 \%) \quad 1(4.0 \%) \quad 6(3.23 \%)$

$\begin{array}{lllll}4000- & 151(93.79 \%) & 23(92.0 \%) & 174(93.55 \%) & 0.499\end{array}$

$>5000 \mathrm{cGy} \quad 5(3.11 \%) \quad 1(4.0 \%) \quad 6(3.23 \%)$

* CEA: carcinoembryonic antigen

The CEA (carcinoembryonic antigen) level was not found in five patients, all of them also from Group 1 and in 21 $(9.9 \%)$ the interval between neoadjuvant therapy and surgery were not obtained (18 from in Group 1 and 3 from Group 2). Six $(2.8 \%)$ patients were submitted to derivative colostomy because of intestinal obstruction before neoadjuvant therapy, four from the Group 1 and 2 from the Group 2. The surgical findings, pathological and postoperative follow-up data are shown in the Table 2.

Out of 182 patients with residual lesion, the histological grading of tumor was undifferentiated or poorly differentiated in $18(9.9 \%)$ patients, moderately differentiated in 152 $(83.5 \%)$ and well differentiated in other $12(6.6 \%)$.

Regarding disease-free survival, there was significant difference between the Groups 1 and 2, with 85.5 months (ranging from 0 to 152 ) and 134.6 months (ranging from 1 to 166), respectively $(P=0.004)$ (Figure 1$)$. The overall survival was 94.1 months (ranging from 0 to 152) for the Group 1 and 136.4 months (ranging from 1 to 166) for the Group 2 $(P=0.02)$ (Figure 2). 
TABLE 2. Surgical, pathologic and follow-up data

\begin{tabular}{lcccc}
\hline & Group 1 & Group 2 & Total & $\boldsymbol{P}$ \\
\hline $\begin{array}{l}\text { Synchronous } \\
\text { metastases }\end{array}$ & $28(15.4 \%)$ & $3(10.0 \%)$ & $31(14.6 \%)$ & 0.583 \\
$\begin{array}{l}\text { Type of surgery } \\
\text { RTS* + colorectal }\end{array}$ & $48(26,4 \%)$ & $06(20 \%)$ & $54(25,5 \%)$ & \\
$\begin{array}{l}\text { anastomosis } \\
\text { RTS* + coloanal }\end{array}$ & $32(17.6 \%)$ & $09(30 \%)$ & $41(19,3 \%)$ & 0.423 \\
$\begin{array}{l}\text { anastomosis } \\
\text { Abdominoperineal }\end{array}$ & $99(54,4 \%)$ & $15(50 \%)$ & $114(53,8 \%)$ & \\
$\begin{array}{l}\text { resection } \\
\begin{array}{l}\text { Others } \\
\text { Affected lymph }\end{array}\end{array}$ & $03(1,6 \%)$ & 0 & $03(1,4 \%)$ & \\
$\begin{array}{l}\text { nodes (average) } \\
\text { Lymphatic Invasion }\end{array}$ & $35(19,2 \%)$ & $1(3,3 \%)$ & $36(17,0 \%)$ & 0,032 \\
$\begin{array}{l}\text { Perineural Invasion } \\
\text { Examined lymph }\end{array}$ & $28(15,4 \%)$ & $0(0 \%)$ & $28(13,2 \%)$ & 0,017 \\
$\begin{array}{l}\text { nodes (average) } \\
\text { Local recurrence }\end{array}$ & $16.3(0-78)$ & $13.9(0-87)$ & $16.0(0-87)$ & 0.023 \\
$\begin{array}{l}\text { Metastasis } \\
\text { (follow-up) }\end{array}$ & $25(15 \%)$ & $1(3.4 \%)$ & $26(13.3 \%)$ & 0.32 \\
\hline
\end{tabular}

* RTS: rectosigmoidectomy

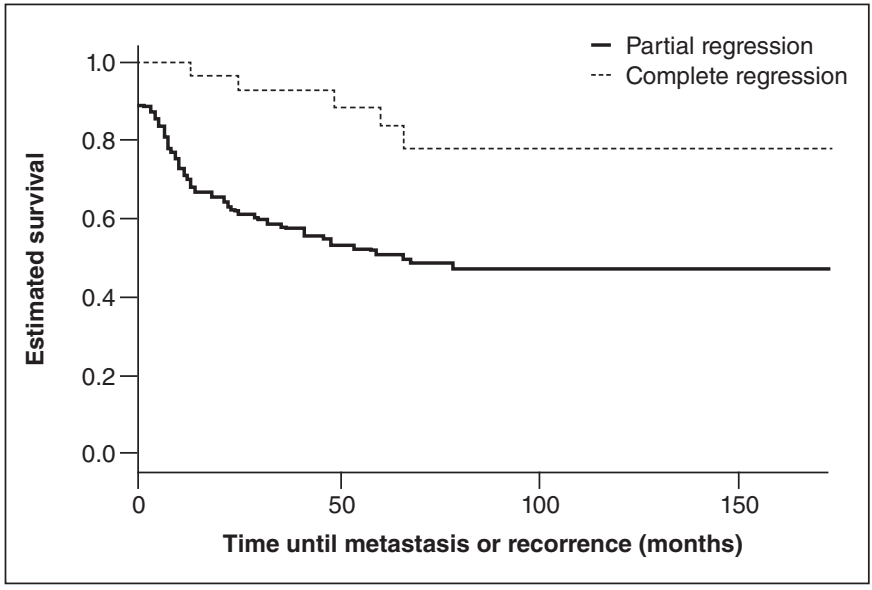

FIGURE 1. Disease-free survival of patients with and without total tumor regression after neoadjuvant therapy $(P=0.004)$

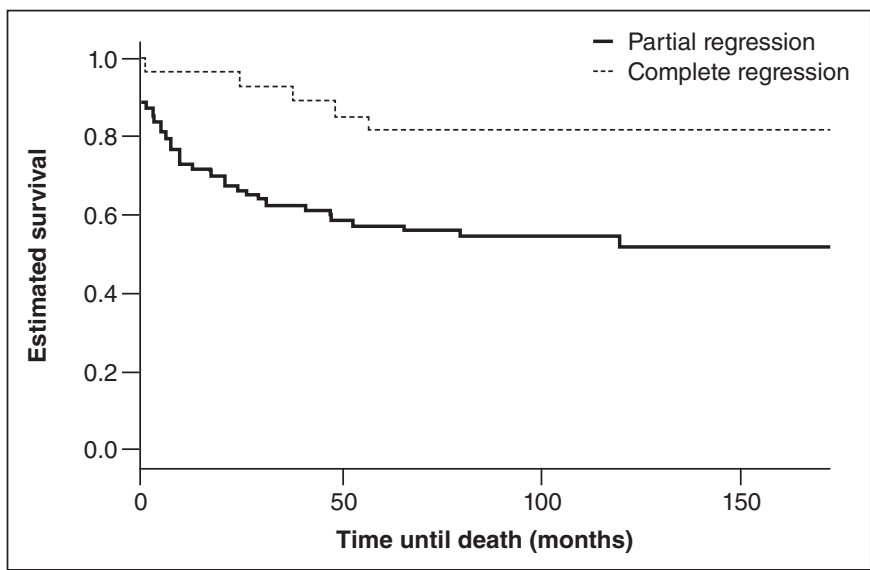

FIGURE 2. Overall survival of patients with and without total tumor regression after neoadjuvant therapy $(P=0.02)$

\section{DISCUSSION}

The treatment for extra-peritoneal rectal cancer has been preferably carried out by a multimodal approach that includes chemoradiotherapy followed by total mesorectal excision surgery. Studies comparing neoadjuvant therapy with radiotherapy and chemotherapy, and radiotherapy alone before surgery, or even, with radio and chemotherapy postoperative, showed that these are worse outcomes than the neoadjuvant therapy, and the adjuvant therapy is reserved only for patients after surgical treatment that showed disease in lymph nodes in the surgical specimen ${ }^{(21)}$.

The introduction of neoadjuvant therapy was considered a hallmark in the management of rectal cancer as it resulted in considerable tumor remission rates, with reduced local recurrence and improved the patient's survival. In the literature, pathologic complete response varies from $0 \%$ to $42 \%$, with the best results found when radiotherapy is associated with two chemotherapy drugs ${ }^{(10,24)}$. The tumor regression observed in the rectal wall is not often accompanied by tumor remission in the lymph nodes. In our study, $10 \%$ of patients had metastatic lymph nodes in the group with total tumor remission, the same percentage found by Shwaartz et al. ${ }^{(25)}$.

In the present study, complete remission was considered the absence of viable tumor cells in the rectal wall in the surgical specimen, and were observed in 30 patients, representing $14 \%$ of the sample, as found by other authors Nyasavajjala et al. ${ }^{(20)}(10 \%)$, Jeong et al..$^{(15)}(17 \%)$ and Garland et al. ${ }^{(9)}(11.4 \%)$. However, this data was slightly lower than the best results, perhaps suggesting differences in the neoadjuvant treatment and especially in the interval between neoadjuvant therapy and surgery.

This study aimed to assess the differences between groups of patients with complete regression of the rectal tumor with those who maintained residual lesion. The analysis of preoperative data revealed no differences between the two groups with respect to age, gender, ethnicity, distance between from the tumor and the anal verge, dose of radiotherapy, occurrence of synchronous lesions or metastases and type of surgery performed.

The level of CEA, in the comparison between the two groups, tended to a significant difference $(P=0.067)$, showing that in patients who responded with complete remission of the primary tumor, the level was less than or equal to 5.0 $\mathrm{ng} / \mathrm{mL}$ in the preoperative in a larger number of patients. Park et al. ${ }^{(22)}$ also found an association between higher CEA levels than $5.0 \mathrm{ng} / \mathrm{mL}$ and a worse response to neoadjuvant treatment and Yoon et al. ${ }^{(28)}$ found relationship between a positive response and CEA levels less than $5.0 \mathrm{ng} / \mathrm{mL}$. Zeng et al. ${ }^{(29)}$, in a study conducted with 323 patients, the value of pretreatment CEA less than or equal to $5 \mathrm{ng} / \mathrm{mL}$, was considered an independent clinical predictor for pathological complete response.

The benefit of preoperative chemoradiotherapy is well established in the literature, but the best interval between neoadjuvant therapy and surgical treatment is not fully defined. The key point is that the necrosis induced by radiotherapy 
appears to be time dependent, so a controlled postpone surgery would allow a potentiation of the effect, maximizing the benefits of neoadjuvant therapy ${ }^{(12,15)}$.

At first, in 1999, François et al. ${ }^{(8)}$ through Trial Lyon R90-01, found a complete pathological response in $10.3 \%$ of the patients operated shortly time ( 2 weeks) after neoadjuvant therapy, and $26 \%$ with a longer interval ( 6 to 8 weeks). Based on these results, since then, most units adopted this interval of 6-8 weeks between the end of neoadjuvant therapy and surgery.

Saglam et al. ${ }^{(23)}$ did not observe differences in pathological response rate, local recurrence of the disease, metastasis and overall survival between patients operated between 4 and 8 weeks, and after 8 weeks of neoadjuvant therapy. Similarly, Jeong et al. ${ }^{(15)}$ found no differences in survival, local recurrence, distant metastasis and tumor response rate, however they showed a better complete pathological response rate in the lymph nodes in the patients operated after 8 weeks of the completion of neoadjuvant therapy ( $66.7 \%$ vs $46.7 \%$; $P=0.024$ ).

Habr-Gama et al. ${ }^{(12)}$, analyzing 250 patients, also observed a better pathological response in the lymph nodes when they were operated with a long time after the neoadjuvant therapy. They compared the group of patients operated with 12 or fewer weeks $(48 \%)$ and after 12 weeks $(52 \%)$ and found a lower significantly risk of lymph nodes involvement in the group operated after 12 weeks $(P=0.015)$. There was no statistical difference between the two groups with respect to overall survival rate $(86 \%$ and $81.6 \%)$ and disease-free survival $(56.5 \%$ and $58.8 \%)$.

Still regarding the optimal time to perform surgery after the neoadjuvant therapy, Foster et al. ${ }^{(7)}$, in a meta-analysis including 15 studies, concluded the evidence is insufficient to settle this time though there appear to be benefits after 6-8 weeks.

In our study, in patients with residual disease, there was no difference between the patients operated before and after 8 weeks from the end of neoadjuvant therapy, but the Group with total remission, $71.1 \%$, were operated with intervals of less than 8 weeks, and this difference had statistical significance $(P=0.027)$. Therefore, we found that total remission occurred more frequently in patients operated with shorter intervals or equal to 8 weeks, contrary to the findings of other studies. We are conducting new surveys in our unit to explain these results, since the current trend is to wait more time between neoadjuvant therapy and surgery. Perhaps with a larger sample size and studying different intervals, and not just more or less than 8 weeks, we will have other conclusions.

Recurrence of the disease, locally or at distance, and quality of life of patients are important factors in the management of rectal cancer. Poor histological differentiation, angiolymphatic and perineural invasion, advanced stage and elevation of CEA in the preoperative are factors associated with worse prognosis ${ }^{(27)}$. However, despite advances in detection and tumor staging, the characterization of lymph node involvement remains unclear. Considering patients with complete tumor response in the rectum, $7 \%$ to $17 \%$ will have tumor involvement of lymph nodes ${ }^{(19,21)}$; and in our study, this percentage was $10 \%$. The preoperative analysis in order to select patients for a non-surgical treatment therefore, can jeopardize a percentage of patients with lymph node involvement, regardless of tumor regression in the rectum ${ }^{(1)}$.

The pathologic evaluation of the lymph nodes of surgical specimens from patients with rectal cancer can have substantial impact on time to relapse and survival. The ideal number of lymph nodes evaluated in the surgical specimen has been controversial, but an inadequate number can lead to understaging, and then require adjuvant therapy ${ }^{(13)}$. Currently, it is considered a minimum 12 lymph nodes examined for proper staging ${ }^{(16,18,27)}$.

Our series showed an average 16.3 lymph nodes in Group 1 and 13.9 in Group $2(P=0.023)$ and average of affected lymph nodes 1.9 and 0.5 , respectively $(P=0.003)$. These results may suggest that neoadjuvant therapy was more effective in the Group with complete pathological response also in relation to the lymph nodes, justifying a lower number of total and metastatic lymph nodes. Habr-Gama et al. ${ }^{(13)}$ also observed that patients with more than 14 lymph nodes examined, and classified as N0, presented significantly higher absence rates of residual disease and longer survival compared with lower number of lymph nodes. In this study, in the group with total remission of the rectal lesion, there was only a patient with angiolymphatic involvement and there was no perineural involvement.

Published data show that $50 \%$ to $60 \%$ of patients with rectal cancer will develop distant metastases, especially liver, lung, bone and brain ${ }^{(18)}$. In our series, the global index of metastatic disease with median follow-up of 28.3 months was $26 \%$, being $28 \%$ in patients with residual tumor and $13.8 \%$ in the Group with complete remission $(P=0.26)$.

Local recurrence is another factor directly related to survival, with rates ranging from $3 \%$ to $30 \%$, with a significant reduction from the advent of the total mesorectal excision and neoadjuvant therapy. Relapse, usually occurs within the first year, over $90 \%$ occurring until third year of postoperative. Several factors may be related to these rates, as the presence of lymph nodes metastases, scanty or positive margins and penetration in the rectal wall ${ }^{(10)}$.

In the overall analysis of our series, $13.3 \%$ of patients had pelvic recurrence, with no differences between the Groups (15\% in Group 1 and $3.4 \%$ in Group 2; $P=0.32$ ). A metaanalysis conducted by Martin et al. ${ }^{(17)}$, which included 16 studies and 3,363 patients, found in patients with complete tumor remission, a local recurrence of $0.7 \%$ and the distant metastases of $8.7 \%$. Our percentage of local relapse of 3.4\% in patients with complete remission refers to only one patient, so if it were a larger sample, this number would probably approach the rates found in this meta-analysis.

Regarding survival, the Group with total remission of the tumor in the rectum showed greater overall survival $(P=0.02)$ and disease-free survival $(P=0.004)$, findings also observed in the Stipa et al. ${ }^{(26)}$ study, who showed a rate of $96 \%$ diseasefree survival and overall survival of $90 \%$ in patients with complete pathologic remission, after 5 years of follow-up. 
Our study has limitations, mainly because it is retrospective and the information is collected from medical records with possible loss of some data. During this time also there was a great evolution especially in relation to chemotherapy and perhaps new studies will show a higher rate of complete pathological response and with the improvement in the accuracy of staging exams after neoadjuvant therapy, non-operative treatment might become the most appropriate option in the future.

However, up to the present date, chemotherapy combined with radiotherapy followed by total mesorectal excision surgery is still the pattern in the treatment of rectal cancer ${ }^{(2,21)}$. In this study, patients with complete tumor remission in the rectum wall had a lower number of metastatic lymph nodes, less angiolymphatic and perineural involvement, in addition to greater overall and disease-free survival. Moreover, they also showed a tendency of lower value in the preoperative CEA and better response when they were operated within 8 weeks or less after neoadjuvant therapy. Although the complete pathologic remission was associated with better prognosis, this not implied in the cure for all patients.

\section{Authors' contributions}

Andrade VA: data collection, statistical analysis, writing of text and text revision. Ayrizono MLS: advisor. All authors drafted the article and gave final revision.

Andrade VA, Coy CSR, Leal RF, Fagundes JJ, Martinez CAR, Ayrizono MLS. Terapia neoadjuvante e cirurgia para câncer do reto. Estudo comparativo entre resposta patológica parcial e completa. Arq Gastroenterol. 2016,53(3):163-8.

RESUMO - Contexto - A abordagem do câncer retal extra-peritoneal localmente avançado implica em um tratamento com quimio e radioterapia neoadjuvante associada com a cirurgia de excisão total do mesorreto. Entretanto, os tumores respondem de maneiras variadas a esta terapia neoadjuvante, não se conhecendo completamente os mecanismos envolvidos nesta resposta. Objetivo - Avaliar os fatores relacionados à resposta tumoral completa e o seguimento de pacientes operados, comparando o grupo com regressão parcial com aqueles em que se evidenciou remissão total da lesão no reto, pelo estudo anatomopatológico. Métodos - Análise retrospectiva de prontuários médicos de 212 pacientes operados entre 2000 e 2010, sendo que 182 (85,9\%) apresentaram remissão parcial a neoadjuvância (Grupo 1) e 30 (14,1\%), remissão total (Grupo 2). Resultados - Não foi encontrada diferença entre os grupos em relação a gênero, etnia, idade, distância do tumor a margem anal, ocorrência de metástases e lesões sincrônicas no estadiamento pré-operatório, dose de radioterapia e tipo de cirurgia realizada. No Grupo 2 , foi verificada alta taxa de remissão completa quando o paciente foi operado com intervalo menor ou igual a 8 semanas após a terapia neoadjuvante $(P=0,027)$, e uma tendência a menor valor de antígeno carcinoembrionário pré-tratamento $(P=0,067)$. Na análise patológica, o Grupo 1 apresentou em relação ao Grupo 2, mais linfonodos acometidos (média de 1,9 e 0,5 respectivamente; $P=0,003$ ), mais invasão angiolinfática $(19,2 \%$ e $3,3 \% ; P=0,032)$ e perineural $(15,4 \%$ e $0 \% ; P=0,017)$, e maior número de linfonodos examinados $(16,3$ e 13,$6 ; P=0,023)$. No seguimento tardio, o Grupo 1 também apresentou menor sobrevida global do que o Grupo 2 (94,1 e 136,4 meses, respectivamente; $P=0,02)$ e sobrevida livre de doença $(85,5$ e 134,6 meses; $P=0,004)$. Não houve diferença estatística entre os Grupo 1 e Grupo 2 na ocorrência de recidiva local $(3,4 \%$ e $15 \%$, respectivamente; $P=0,32)$ e metástases à distância $(13,8$ e 28\%; P=0,26). Conclusão - Neste estudo, o único fator que foi associado à remissão completa do adenocarcimona retal, foi o tempo entre neoadjuvância e a cirurgia. Este grupo de pacientes apresentou menos linfonodos acometidos, menor invasão angiolinfática e perineural, maior sobrevida global e livre de doença, porém não apresentou diferença estatística significativa com relação à recorrência local e metástases à distância. Embora a remissão completa fosse associada com melhor prognóstico, não implicou na cura da doença em todos os pacientes.

DESCRITORES - Terapia neoadjuvante. Cirurgia colorretal. Neoplasias retais. 


\section{REFERENCES}

1. Andrade VA, Leal RF, Fagundes JJ, Coy CSR, Ayrizono MLS. Neoadjuvant therapy and surgery in rectal adenocarcinoma: Analysis of patients with complete tumor remission. J Coloproctol. 2013;33:222-7.

2. Artioukh DY. Controversial aspects of rectal cancer surgery. Colorectal Dis. 2010;12:25-9.

3. Chang GJ, Rodriguez-Bigas MA, Eng C, Skibber JM. Lymph Node Status After Neoadjuvant Radiotherapy for Rectal Cancer Is a Biologic Predictor of Outcome. Cancer. 2009; 115:5432-40.

4. Chok KS, Law WL. Prognostic factors affecting survival and recurrence of patients with pT1 and pT2 colorectal cancer. World J Surg. 2007;31:1485-90.

5. Compton CC, Fielding LP, Burgart LJ, Conley B, Cooper HS, Hamilton SR, et al. Prognostic factors in colorectal cancer. Arch Pathol Lab Med. 2000;124:979-94.

6. Eich HT, Stepien A, Zimmermann C, Hellmich M, Metzger R, Hölscher A, Müller RP. Neoadjuvant Radiochemotherapy and Surgery for Advanced Rectal Cancer Prognostic Significance of Tumor Regression. Strahlenther Onkol. 2011;187:225-30.

7. Foster JD, Jones EL, Falk S, Cooper EJ, Francis NK. Timing of surgery after long-course neoadjuvant chemoradiotherapy for rectal cancer: a systematic review of the literature. Dis Colon Rectum. 2013;56:921-30.

8. Francois Y, Nemoz CJ, Baulieux J, Vignal J, Grandjean JP, Partensky C, et al. Influence of the interval between preoperative radiation therapy and surgery on downstaging and on the rate of sphincter-sparing surgery for rectal cancer: the Lyon R90-01 randomized trial. J Clin Oncol. 1999;17:2396.

9. Garland ML, Vather R, Bunkley N, Pearse M, Bissett IP. Clinical tumour size and nodal status predict pathologic complete response following neoadjuvant chemoradiotherapy for rectal cancer. Int J Colorectal Dis. 2014;29:301-7.

10. Habr-Gama A, Perez RO, Nadalin W, Sabbaga J, Ribeiro U Jr, Silva e Sousa AH $\mathrm{Jr}$, et al. Operative versus nonoperative treatment for stage 0 distal rectal cancer following chemoradiation therapy: long-term results. Ann Surg. 2004;240:711-7.

11. Habr-Gama A, Perez RO, Proscurshim I, Campos FG, Nadalin W, Kiss D, Gama-Rodrigues J. Patterns of failure and survival for nonoperative treatment of stage $\mathrm{c} 0$ distal rectal cancer following neoadjuvant chemoradiation therapy. $\mathbf{J}$ Gastrointest Surg. 2006;10:1319-28.

12. Habr-Gama A, Perez RO, Proscurshim I, Nunes RMS, Kiss D, Gama-Rodrigues $\mathrm{J}$, Cecconello I. Interval between surgery and neoadjuvant chemoradiation therapy for distal rectal cancer: does delayed surgery have an impact on outcome? Int J Radiat Oncol Biol Phys. 2008;71:1181-8.

13. Habr-Gama A, Perez RO, Proscurshim I, Rawet V, Pereira DD, Sousa AH, Kiss D, Cecconello I. Absence of lymph nodes in the resected specimen after surgery for distal rectal cancer and neoadjuvant chemoradiation therapy: what does it mean? Dis Colon Rectum._2008;51:277-83.

14. Hetnal M, Malecki K, Korzeniowski S, Zemelka T. Postoperative chemoradiotherapy in patients with rectal cancer, prognostic factors for disease control and survival. J Clin Oncol. 2006;24:13575.
15. Jeong DH, Lee HB, Hur H, Min BS, Baik SH, Kim NK. Optimal timing of surgery after neoadjuvante chemoradiation therapy in locally advanced rectal cancer. J Korean Surg Soc. 2013;84:338-45.

16. Lykke J, Jess P, Roikjaer O. A minimum yield of twelve lymph nodes in rectal cancer remains valid in the era of neo-adjuvant treatment. Int J Colorectal Dis. 2015;30:347-51.

17. Martin ST, Heneghan HM, Winter DC. Systematic review and meta-analysis of outcomes following pathological complete response to neoadjuvante chemoradiotherapy for rectal cancer. Br J Surg. 2012;99:918-28.

18. Meredith KL, Hoffe SE, Shibata D. The multidisciplinary management of rectal cancer. Surg Clin North Am._2009;89:177-215.

19. Nan KJ, Qin HX, Yang G. Prognostic factors in 165 elderly colorectal cancer patients. World J Gastroenterol. 2003;9:2207-10.

20. Nyasavajjala SM, Shaw AG, Khan AQ, Brown SR, Lund JN. Neoadjuvan chemo-radiotherapy and rectal cancer: can the UK watch and wait with Brazil? Colorectal Dis. 2009;12:33-6.

21. O'Neill BD, Brown G, Heald RJ, Cunningham D, Tait DM. Non-operative treatment after neoadjuvant hemoradiotherapy for rectal cancer. Lance Oncol. 2007;8:625-33.

22. Park YA, Sohn SK, Seong J, Baik SH, Lee KY, Kim NK, Cho CW. Serum CEA as a predictor for the response to preoperative chemoradiation in rectal cancer. J Surg Oncol. 2006;93:145-50.

23. Saglam S, Bugra D, Saglam EK, Asoglu O, Balik E, Yamaner S, et al. Fourth versus eighth week surgery after neoadjuvant radiochemotherapy in T3-4/ N0+ rectal cancer: Istanbul R-01 study. J Gastrointest Oncol. 2014;5:9-17.

24. Sanghera P, Wong DW, McConkey CC, et al. Chemoradiotherapy for recta cancer: An updated analysis of factors affecting pathological response. Clin Oncol R Coll Radiol. 2008;20:176-83.

25. Shwaartz C, Haim N, Rosin D, Lawrence Y, Gutman M, Zmora O. Regional lymph node status after neoadjuvant chemoradiation of rectal cancer producing complete or near complete rectal wall response. Colorectal Dis. 2015; 17:595-9.

26. Stipa F, Chessin DB, Shia J. A pathologic complete response of rectal cancer to preoperative combined-modality therapy results in improved oncological outcome with those who achieve no downstaging on the basis of preoperative endorectal ultrasonography. Ann Oncol. 2006;13:1047-53.

27. Tepper JE, O'Connell MJ, Niedzwiecki D, Hollis D, Campton C, Benson III $\mathrm{AB}$, et al. Impact of number of nodes retrieved on outcome in patients with rectal cancer. J Clin Oncol. 2001;19:157-63.

28. Yoon SM, Kim DY, Kim TH, Jung KH, Chang HJ, Koom WS, et al Clinical parameters predicting pathologic tumor response after preoperative chemoradiotherapy for rectal cancer. Int J Radiat Oncol Biol Phys. 2007;69:1167-72.

29. Zeng WG, Liang JW, Wang Z, Zhang XM, Hu JJ, Hou HR, et al. Clinical parameters predicting pathologic complete response following neoadjuvant chemoradiotherapy for rectal cancer. Chin J Cancer. 2015;13:34-41. 